\section{Changes to the MRCPsych examination - an update}

The proposed changes to the MRCPsych examinations were published in the Bulletin in July 2000 (Katona et al, July 2000, 24, 276-278). The timetable for the changes to the examination were indicated in the article.

After further discussions by the Implementation Working Group, the body that is concerned with the logistics of implementing the changes to the MRCPsych examination, two changes have been recommended of which candidates and examiners should be aware.

(a) The new extended matching items (EMI) questions will be introduced into the MRCPsych Part I examination in Spring 2003 as planned. It has been demonstrated that EMI questions test a wider range of clinical skills than the multiple choice question (MCQ) format. In a recent pilot examination of EMl questions in Part I of the examination in Autumn 2000 these questions were found to have good psychometric properties in terms of distinguishing between good and bad candidates, and were acceptable to the candidates. EMI questions will therefore replace part of the MCQ examination so that in future the written section of the Part I examination will consist of both MCQ and EMI questions. Examples are to be found on the College website (http://www.rcpsych.ac.uk/ traindev/exams/regulation/ emisamp.htm). Alternative formats are being developed in a further pilot examination in Spring 2002 for both parts of the examination and examples of these will be posted on the website. However, EMI questions will not be included in the Part II examination until Autumn 2003.

(b) The revised curriculum for basic specialist psychiatry training and for the MRCPsych examination is scheduled for publication within the next 3 months. In the Autumn 2001 MRCPsych examinations candidates should be aware that the questions set in both parts of the examinations will be based on the old curriculum. Sufficient time will therefore be available for candidates to examine the revised curriculum, which will be used as a basis for the questions set in both the written and clinical papers in the Spring 2002 examination.

StephenTyrer Chief Examiner, Simon Fleminger Chairman, EMI Working Group

\section{Election of Sub-Deans}

Council will be electing Sub-Deans at its meeting on Wednesday 31 October 2001.
There are currently four Sub-Deans, three of whom are eligible for re-election. The Sub-Deans work closely with the Dean, Professor Cornelius Katona, and it is likely that the successful candidate will work in the area of examinations.

If you would like further information please contact Professor Cornelius Katona by 1 October 2001 (e-mail: ckatona@ rcpsych.ac.uk).

Vanessa Cameron Secretary, Royal College of Psychiatrists, 17 Belgrave Square, London SW1X 8PG

\section{Royal College of Psychiatrists' Board of International Affairs}

Just as in the 19th century, when it was realised that public health - or ill health was often the product of poor social conditions requiring municipal and national action to address it, so in the 21st century it is evident that many of the factors that determine health now require international action. The immediate threats to global health include overconsumption, environmental damage and misuse of medicines, and many international forums have focused on the consequences for physical health. However, as countries address these more tangible problems and improve the physical health of their population, their mental health needs become more apparent and more pressing. In many countries these needs are acknowledged and appropriate training for health care professionals is provided and/or is being developed. However, with the growing gulf in prosperity between rich countries and poor, it is important that mental health services in the latter do not become - or do not continue to be - the Cinderella services that they were for so many years in the UK.

Our College, with its tradition and reputation of experience in postgraduate education and its historical links with many countries, is well placed to play a role in the direct provision of training that should be appropriate to the needs of the country concerned and should not seek to exploit its workforce to remedy service deficiencies in the UK.

A continuing contribution to international education, although an important responsibility, should be seen as the starting point for the College's future global role, rather than an end-point. As a starting point it allows the development of relationships with the people likely to become leaders of the discipline within different countries, and it also offers the College - and through the College, the profession as a whole - the opportunity to learn from other countries' experiences about cultural differences, different pathologies, different treatment approaches and so on. This development of genuine partnerships between equals, benefiting all parties, is of fundamental importance for the College's internationa role. The decline in the number of overseas trainees in recent years is evidence and warning that the old ways are no longer sufficient.

Instead, the College must reach out and become involved not just with the English-speaking Commonwealth countries, but increasingly with the countries in the European Economic Area. This will require the College to be wholeheartedly committed to organisations such as the World Psychiatric Association, the Association of European Psychiatrists and the World Health Organization, as well as developing strong links with sister organisations in other countries.

We appreciate that any such efforts require significant investment of precious time and money. This investment is essential, not just for the College's continued international prestige, but also because of our responsibility to advocate actively equality of mental health worldwide. Our concern must be for the mental health of all the world's citizens, not just the 'mental health of the nation'.

Finally, remembering the not too distant history of the use of psychiatry for political purposes, the Royal College of Psychiatrists should lead the way in advocacy of human rights, individual freedom and ethical and moral issues, which are fundamental to good mental health.

Hamid Ghodse Vice-President and Director of International Affairs

\section{Invitation}

The Board of International Affairs has been set up by Council with a specific remit to make recommendations and comment on recommendations or decisions by other College committees whenever these have international implications. The Board will meet at least four times a year. It has its own office and the administrative support at the College. But this is just a beginning.

You are hereby invited to help us to define specific issues that, in the light of the above article, you think we should be concentrating on, by applying for one of the posts of Appointed Member of the Board of International Affairs.

This is an honorary post and it is probable that you will need to devote 